\title{
A technological approach to the morphofunctional classification of seedlings of 50 Brazilian forest species ${ }^{1}$
}

\author{
Gabriela Alves Lobo², Denise Garcia de Santana ${ }^{2 *}$, Antonieta Nassif Salomão ${ }^{3}$, \\ Luciana Salazar Rehbein ${ }^{2}$, Angélica Polenz Wielewicki ${ }^{4}$
}

\begin{abstract}
A technological approach to the morphofunctional classification of forest species seedlings defines the essential structures in the evaluation of germination testing and identifies changes in this structures that suggest abnormalities. The objective was to associate morphofunctional seedling classification to seed germination testing using official germination methods for 50 forest species from Amazon, Caatinga, Cerrado, Atlantic Forest and Pantanal biomes. Morphofunctional classification and abnormalities were defined using seedlings from 232 germination pre-tests and 1,160 samples that were formed for each species using seeds from distinct locations and with at least three levels of vigor. The phanero-epigeal germination with a non-developed epicotyl predominated among species (84\%). Common in hypogeal germination, the development of the epicotyl occurred only in seedlings of Anadenanthera colubrina and Erythrina speciosa, both with epigeal germination. The need to supply and sustain the great mass produced in its long life cycle, the presence of the primary root was considered essential for the normal seedling classification of these forest species. Curled, stunted, necrotic, bifurcated primary root and those retained in the seed coat or in the fruit structures, were the main abnormalities of the seedling root systems. Damages to the shoot system were uncommon.
\end{abstract}

Index terms: abnormal seedlings, epigeal germination, hypogeal germination, tropical specie.

\section{Abordagem tecnológica da classificação morfofuncional de plântulas de 50 espécies florestais brasileiras}

\begin{abstract}
RESUMO - A abordagem tecnológica da classificação morfofuncional de plântulas de espécies florestais define as estruturas essenciais na avaliação do teste de germinação e identifica alterações nessas estruturas que sugerem anormalidades. Assim, foi objetivo associar a classificação morfofuncional de plântulas ao teste de germinação usando métodos oficiais para 50 espécies florestais dos Biomas Amazônia, Caatinga, Cerrado, Mata Atlântica e Pantanal. A classificação morfofuncional e as anormalidades foram definidas a partir de plântulas obtidas em 232 pré-testes de germinação com 1.160 amostras, que foram formadas para cada espécie, com sementes coletadas em distintos locais e com, no mínimo, três níveis de vigor. O tipo de germinação phanero-epigeal com epicótilo não desenvolvido predominou entre as espécies (84\%). Comum nas plântulas com germinação hipógea, o desenvolvimento do epicótilo ocorreu apenas em plântulas de Anadenanthera colubrina e Erythrina speciosa, ambas com germinação epígea. Pela necessidade de suprir e sustentar a grande massa produzida no seu longo ciclo de vida, a presença da raiz primária foi considerada essencial para a classificação de plântula normal dessas espécies florestais. A raiz primária enovelada, atrofiada, necrosada, bifurcada, retida no tegumento ou nas estruturas do fruto foram as principais anormalidades do sistema radicular. Danos na parte aérea das plântulas foram pouco frequentes.
\end{abstract}

Termos para indexação: plântulas anormais, germinação epigeal, germinação hipogeal, espécie tropical.

\section{Introduction}

Germination measurements such as capacity, time, velocity, synchrony and uniformity contribute to the

\footnotetext{
${ }^{1}$ Submitted on 10/17/2013. Accepted for publication on 02/07/2014.

${ }^{2}$ Universidade Federal de Uberlândia, Instituto de Ciências Agrárias e Florestais, Caixa Postal 593, 38400-902 - Uberlândia, MG, Brasil.

${ }^{3}$ Embrapa Recursos Genéticos e Biotecnologia, Caixa Postal 02372, 70770-917 - Brasília, DF, Brasil.
}

understanding of the germination process (Ranal and Santana, 2006). Nevertheless, these same measurements are dependent on experimental conditions during germination testing and thus cannot be used to group species. In contrast,

${ }^{4}$ Ministério da Agricultura, Pecuária e Abastecimento, 88102-600 - São José, SC, Brasil.

*Corresponding author <dgsantana@umuarama.ufu.br> 
conservative characteristics such as seedling morphology and structural functionality do make it possible to organize classification systems (Miquel, 1987; Garwood, 1996).

In this context after conducting a floristic survey of the tropical forest tree species from Panama, Garwood (1983; 1996) symbolized five seedling classifications of Miquel (1987), categorizing cotyledons based on exposure, position, texture and function during germination. Some seedling types occur in Brazilian biomes, especially from Amazon that were not described by these authors (Ressel et al., 2004; Camargo et al., 2008). Thus, Miquel's classification has been expanded (Ferraz and Calvi, 2011).

The most common approach to seedling classification is ecological and aimed at understanding the function of structures during seedling establishment and developement. This approach is sometimes referred to as morphofunctional classification (Ibarra-Manríquez et al., 2001; Ressel et al., 2004; Maia et al., 2005; Zanne et al., 2005; Baraloto and Forget, 2007; Alvarez-Clare and Kitajima, 2009). Although uncommon, the technological classification of forest species is indespensable for defining essential seedling structures during germination testing. Moreover, technological classification improves the precision of inferences about abnormalities because it identifies abnormal structural changes. Thus, the objective was to associate morphofunctional seedling classification to seed germination testing using official germination methods for 50 forest species from Amazon, Caatinga, Cerrado Atlantic Forest and Pantanal biomes.

\section{Material and Methods}

The germination test methods for 50 species (Table 1) were officialized by the Brazilian Ministry of Agriculture and Food Supply (Brasil, 2010; 2011; 2012). The validation process was conducted by the Forest Seed Laboratory of the Federal University of Uberlandia, Official Laboratory for Seed Analysis of the Ministry of Agriculture and Food Supply from the state of Rio Grande do Sul and the Seed Laboratory of Embrapa Genetic and Biotechnological Resources in Brasília. The process followed the ISTA Method Validation for Seed Testing (ISTA, 2007).

The 50 species seedling were classified, sensu Ferraz and Calvi (2011), by cotyledon exposure (cryptocotylar and phanerocotylar), and hypocotyl development (hypogeal and epigeal). The development of epicotyl (developed or not) and essentiality of the primary root (essential or not) were classified according to the ISTA Handbook on Seedling
Evaluation (ISTA, 2006).

Each species was morphofunctionally classified using seedlings from 232 germination pre-tests with 1,160 samples. Samples of each species consisted of seeds collected from different locations (provenances) and with at least three vigor levels. The first seedling count was based on high-vigor seeds and the last count was based on low-vigor seeds. Some species also required intermediate countings. To confirm the seedling classifications, approximately 30 seeds from each species were sown in plastic containers $\left(180\right.$ and $\left.280 \mathrm{~cm}^{3}\right)$ filled with a mixture of vermiculite and Bioplant ${ }^{\circledR}$ commercial substrate (1:1, volume:volume). Seedling shoots were qualitatively evaluated between five and 30 days after sowing.

Seedling abnormalities were identified using the defined morphological structures of each species and essentiality criteria. Particularities in seedling morphology were identified, recorded and excluded from the classification of abnormal seedlings.

\section{Results and Discussion}

Most of the seedlings of these 50 forest species had cotyledons that were detached from the seed coat or the epicarp (phanerocotylar), developed hypocotyl (epigeal) and non-developed epicotyl (Table 1). The prevalence of phaneroepigeal seedlings is not restricted to this group of 50 Brazilian forest species. This same trend was found in tropical forest species from Panama (Garwood, 1983), Mexico (IbarraManríquez et al., 2001) and Uganda (Zanne et al., 2005). In Brazil, the highest frequency of this type of seedling was encountered in areas from Amazon Forest (Maia et al., 2005) and in the Cerrado (Ressel et al., 2004).

Only one species had cryptocotylar seedling germination and six had hypogeal germination (Table 1), indicating the low occurance of these seedling types. Indeed, hypogeal and cryptocotylar seedlings are less frequent in tropical forests (Wright et al., 2000; Ibarra-Manríquez et al., 2001; Ressel et al., 2004; Maia et al., 2005). Although, most species with cryptocotylar seedlings have hypogeal germination, there are exceptions (Wright et al., 2000; Ressel et al., 2004).

Regarding the exposure of the cotyledons, some seedlings showed intermediate behavior. Phanerocotylar seedlings of Ormosia arborea (Vell.) Harms and Peltogyne confertiflora (Hayne) Benth. showed partial cotyledon exposure during germination test evaluation (Figures 1d,e). Peltogyne confertiflora cotyledons were exposed through small cracks in the seed coat (Figure 1d). 
Table 1. Morphofunctional classification of seedlings of 50 forest species ${ }^{1}$ from Amazon, Caatinga, Cerrado, Atlantic Forest and Pantanal Biomes.

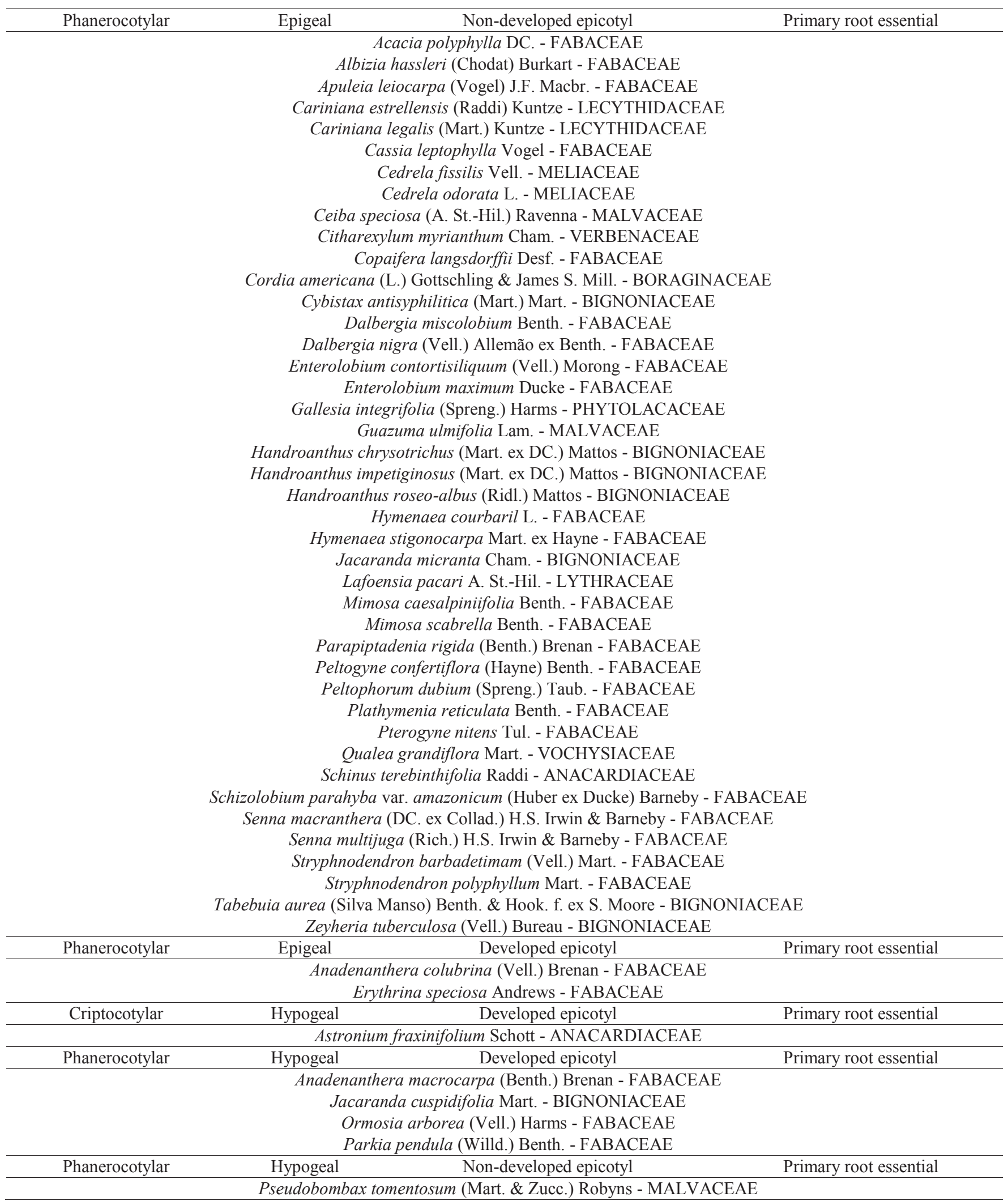

${ }^{1}$ Brazilian species consulted in the TROPICOS base (www.tropicos.org) 


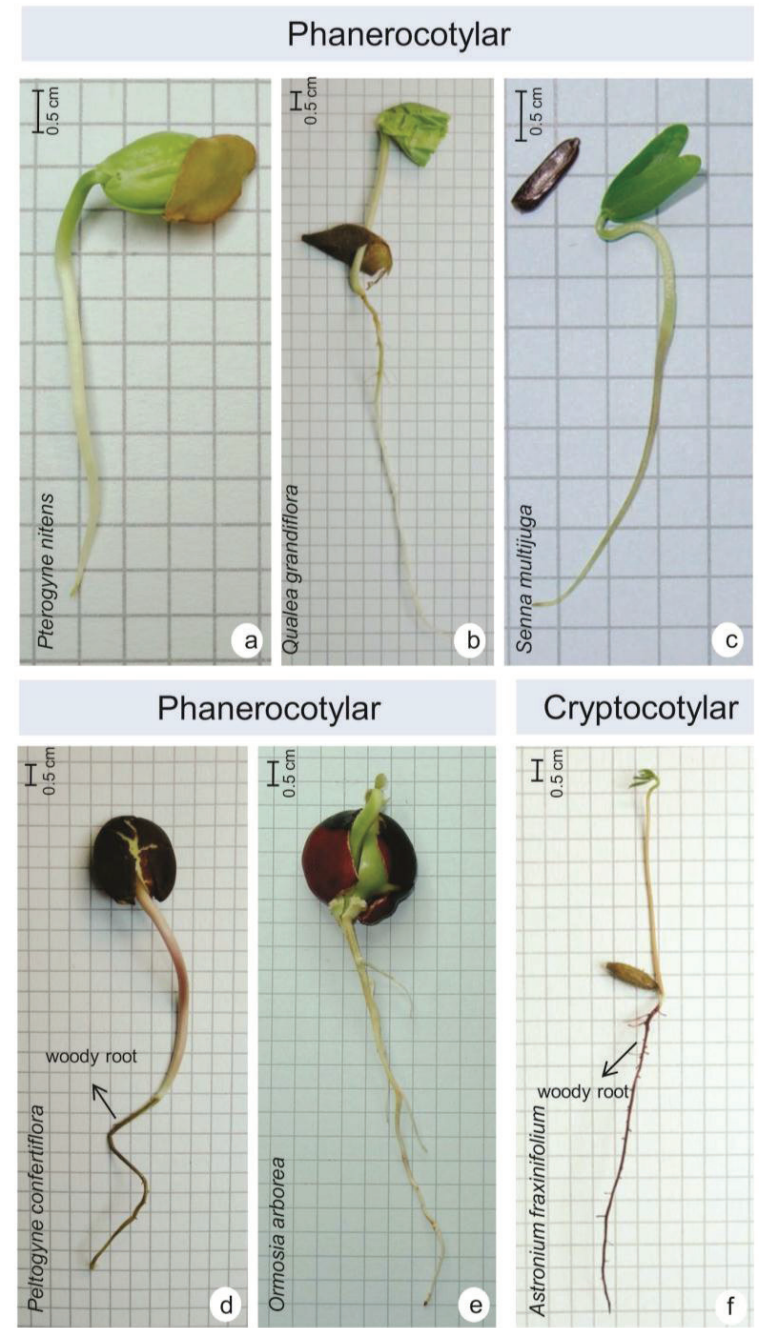

Figure 1. Phanerocotylar germination, free or detached cotyledons (a, b, c, d, e); cryptocotylar germination, cotyledons within the pericarp (f).

Cotyledon position relative to the soil due to hypocotyl development is not restricted to epigeal and hypogeal germination types (Miquel, 1987; Garwood, 1996; Ferraz and Calvi, 2011). Intermediate types such as the semi-hypogeal have been recorded for seedlings of some species that present detached cotyledons (phanerocotylar), remain at soil level and are not elevated by the hypocotyl (Miquel, 1987; Milanez et al., 2008). This type of development has been observed in Anadenanthera macrocarpa (Benth.) Brenan seedlings (Ressel et al., 2004).

According to phylogeny, cogeneric species should have the same morphofunctional classification (Garwood, 1996). Nevertheless, Anadenanthera colubrina (Vell.) Brenan and Anadenanthera macrocarpa seedlings showed epigeal and hypogeal (or semi-hypogeal) germination, respectively (Table 1). This same distinction was found in species of the Jacaranda genus.
Developed epicotyls were a characteristic of epigeal seedlings of Anadenanthera colubrina, and Erythrina speciosa Andrews (Figures 2a, b), however they were uncommon for the other species with epigeal germination (Table 1). All hypogeal seedlings had developed epicotyls (Figures 2d, e) except for Pseudobombax tomentosum (Mart. \& Zucc.) Robyns (Figure 2f). In this specie, cotyledon elevation is caused by cotyledonary petioles. Because these petioles carry out the function of the hypocotyl, the germination was classified as epigeal for Ressel et al. (2004). Seedlings with hypogeal germination have developed epicotyls (Wright et al., 2000; ISTA, 2006).

Epigeal germination with developed epicotyl
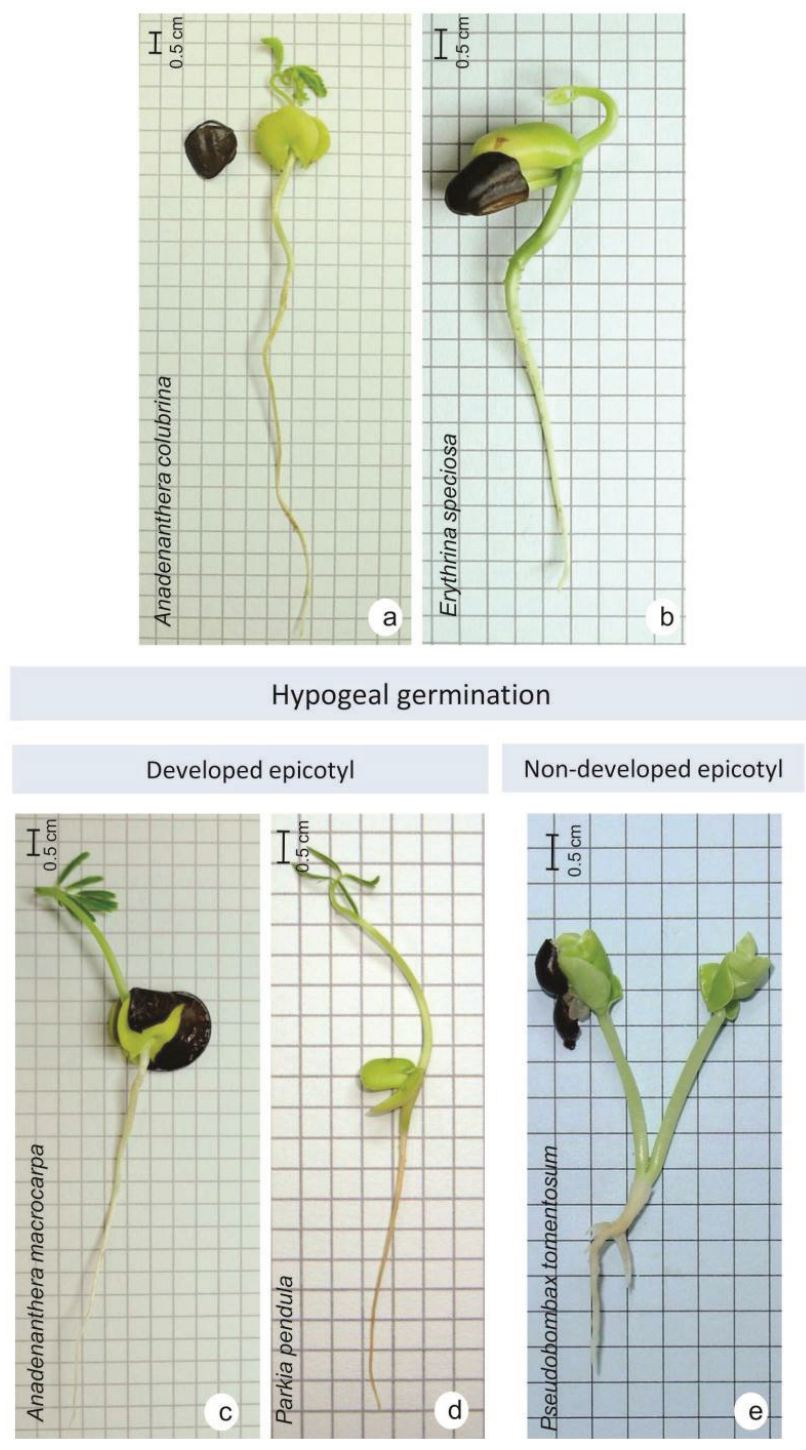

Figure 2. Epigeal germination with developed epicotyl (a, b); hypogeal germination with developed epicotyl (c, d) or non-developed epicotyl (e). 
Primary root essentiality was the only subjective classification used because it was impossible to predict which environmental conditions cause secondary roots to assume the role of absent or deficient primary roots. The presence of the primary root was considered essential to classification as normal seedling. The woody primary roots of Astronium fraxinifolium Schott (Figure 1f), Copaifera langsdorffii Desf., Dalbergia miscolobium Benth., Hymenaea courbaril L., Hymenaea stigonocarpa Mart. ex Hayne, Peltogyne confertiflora (Figure 1d) and Schinus terebinthifolia Raddi seedlings strengthened the essentiality of this structure. Strongly developed secondary roots in seedlings of Erythrina speciosa occurred only when the primary root was already developed.

The primary root was considered one of the most important categories of the importance that the root system has to supply the plant with water and nutrients to sustain the great mass produced during the long life cycle of these forest species. Regardless of biome, secondary roots are common in hypogeal (or semi-hypogeal) seedlings. This suggests that secondary roots may not be essential for seedling with these characteristics. However, primary root essentiality in this seedling category occurs when a species develops tuberous roots as in Amburana cearensis (Arr. Cam.) A.C. Smith (Ramos et al., 2004).

The major abnormalities in seedlings were curled (Figure 3a), stunted (Figures 3 b, d, e, f), bifurcated (Figure 3c) primary roots and primary roots retained in the seed coat (Figures $3 \mathrm{a}, \mathrm{g}$ ) or retained in the floral calyx (Figure 3h). The extensive root structures in these 50 forest seedlings, at the expense of shoot development, preserved structures such as cotyledons, hypocotyls and epicotyl. As a result, there were few seedlings with necrotic cotyledons in more than $50 \%$ of their area (Figures $4 \mathrm{~g}$, h, i), as well as reduced frequencies of hypocotyls that were twisted (Figure 4a), thickened (Figure 4b), and with streaks and cracks, which would affect the conductive tissues (Figures 4c, d, e, f).

The only abnormality found in the epicotyl was its absence in hypogeal seedlings and in the three species possessing epigeal germination and developed epicotyls (Anadenanthera colubrina and Erythrina speciosa). The 50\% rule applied to cotyledon volume was efficient for all species, except for Astronium fraxinifolium Schott. Seedlings of this species had cryptocotylar germination in which the cotyledons were collapsed against the seed coat, unremoveable and indistinguishable from it.

Some characteristics considered abnormal in agricultural species are frequent and thus considered normal in some of these forest species. These characteristics include darkened pigmentation in the cotyledons of Dalbergia miscolobium, darkened pigmentation in the root system of Astronium fraxinifolium (epicotyl and eophylls were also pigmented), Copaifera langsdorffii and Lafoensia pacari A. St.-Hil. seedlings and thickened hypocotyl in Ceiba speciosa (A. St.-
Hil.) Ravenna, Enterolobium contortisiliquum (Vell.) Morong, Hymenaea stigonocarpa and Ormosia arborea seedlings.
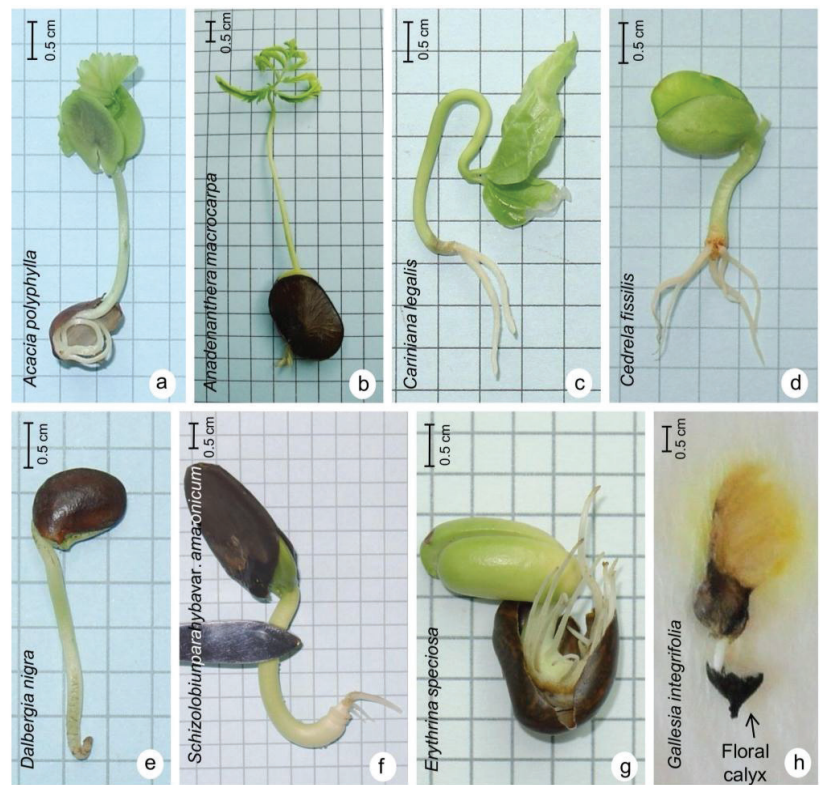

Figure 3. Abnormalities in primary root. Seedlings with primary root curled (a), stunted (b, d, e, f), bifurcated $(\mathrm{c})$, retained in the seed coat $(\mathrm{a}, \mathrm{g})$ and retained in the floral calyx $(\mathrm{h})$.
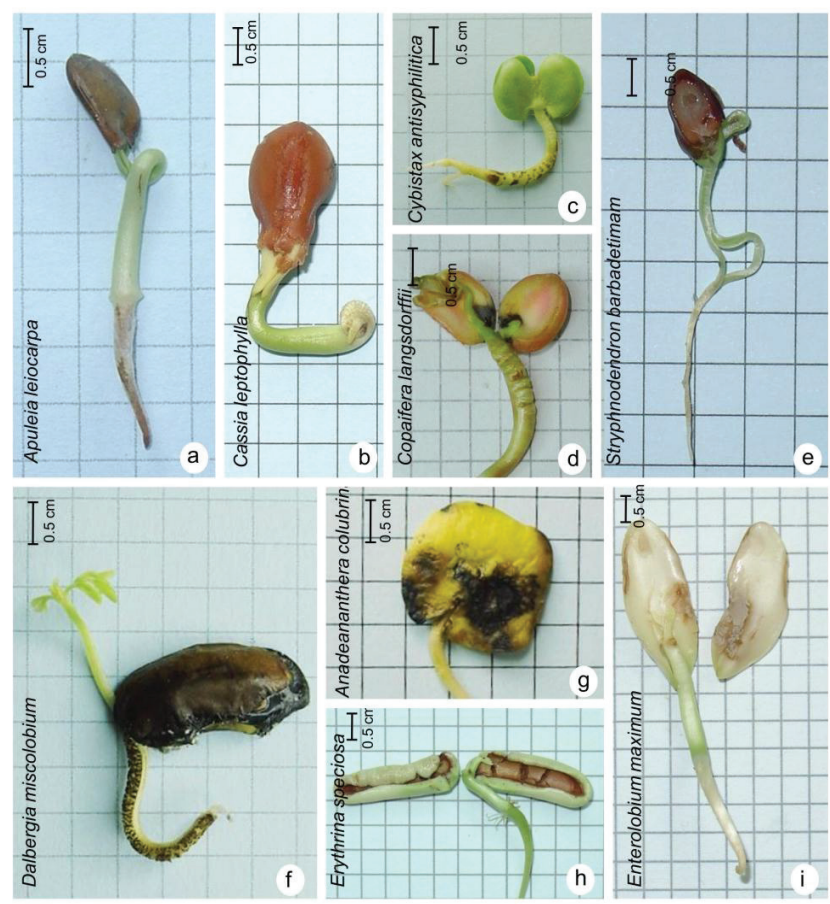

Figure 4. Abnormalities in shoot system. Hypocotyl twisted (a), thickened (b) and with streaks and cracks wich would affect the conductive tissues (c, d, e, f); necrotic cotyledons in more than $50 \%$ of their area $(\mathrm{g}, \mathrm{h}, \mathrm{i})$. 
While morphofunctional classification is useful for evaluating germination tests, it should be remembered that forest species are more prone to phenotypic plasticity than agricultural species. Environmental heterogeneity, seasonal change and the influences of temperature, precipitation photoperiod and resource availability can cause significant plasticity (Chambel et al., 2005). Another factor that differentiates forest species from agriculture species is the great morphological variation in seeds, making it difficult to define appropriate conditions and techniques for germination analysis (Brüning et al., 2011). The forest species are comprised in several botanical families and thus morphological variations of seeds and seedlings are larger than the agriculture species.

Because forest species are long-lived, small seedling defects can be overcome (Ferraz and Calvi, 2011). Consequently, the classification requirements for agricultural species should not be extended to forest species. Despite lower requirements for forest seedlings, the same level of quality is sought for forest and agricultural seedlings. During seedling establishment, forest species are exposed to more pathogens, herbivores, habitat alteration, competition among species and anthropogenic factors (Sarmento and Villela, 2010). Therefore, seedling establishment is the most critical development stage (Garwood, 1996; Hoffmann, 2000; IbarraManríquez et al., 2001) and there are no guarantees that a normal forest seedling will develop into a mature plant. Moreover, measuring the capacity of developing into a mature plant is only predictive.

\section{Conclusions}

According to the technological approach to morphofunctional classification during the germination test, normal seedlings with phanero-epigeal germination should have free cotyledons and a developed hypocotyl. Besides these features, the epicotyl should also be developed in Anadenanthera colubrina and Erythrina speciosa seedlings;

In the germination test, normal seedlings with phanerohypogeal germination must have free cotyledons and a developed epicotyl. For this classification there are exceptions for Pseudobombax tomentosum seedlings for not having developed epicotyls and Astronium fraxinifolium seedlings with pericarp attached to the cotyledons (cryptocotylar);

In the evaluation of the germination test, the presence of the primary root for the seedlings of the 50 species is essential for obtaining a normal seedling classification.

\section{Acknowledgements}

We are grateful for financial support from the National Council on Scientific and Technological Development, the Brazilian Ministry of Agriculture and Food Supply and the Research Suport Foundation of Minas Gerais.

\section{References}

ALVAREZ-CLARE, S.; KITAJIMA, K. Susceptibility of tree seedlings to biotic and abiotic hazards in the understory of a moist tropical forest in Panama. Biotropica, v.41, n.1, p.47-56, 2009. http://onlinelibrary.wiley.com/ doi/10.1111/j.1744-7429.2008.00442.x/pdf

BARALOTO, C.; FORGET, P. Seed size, seedling morphology, and response to deepshade and damage in neotropical rain forest trees. American Journal of Botany, v.94, n.6, p.901-911, 2007. http://www.amjbot.org/content/94/6/901. full.pdf + html

BRASIL. Instrução Normativa $n^{\circ} 26$, de 10 de Setembro de 2012. Diário oficial da República Federativa do Brasil. Poder executivo, Brasília, DF, 11 set. 2012. Seção I, p.5. http://www.in.gov.br/imprensa/visualiza/index. jsp? jornal $=1 \&$ pagina $=5 \&$ data $=11 / 09 / 2012$

BRASIL. Instrução Normativa $\mathrm{n}^{\circ}$ 35, de 14 de Julho de 2011. Diário oficial da República Federativa do Brasil. Poder executivo, Brasília, DF, 15 jul. 2011. Seção I, p.2. http://www.in.gov.br/imprensa/visualiza/index. jsp? jornal $=1$ \&pagina $=2 \&$ data $=15 / 07 / 2011$

BRASIL. Instrução Normativa $n^{\circ} 44$, de 23 de Dezembro de 2010. Diário oficial da República Federativa do Brasil. Poder executivo, Brasília, DF, 24 dez. 2010. Seção I, p.2. http://www.in.gov.br/imprensa/visualiza/index. jsp? jornal $=1$ \&pagina $=2 \&$ data $=24 / 12 / 2010$

BRÜNING, F.O.; LÚCIO, A.D.; MUNIZ, M.F.B. Padrões para germinação, pureza, umidade e peso de mil sementes em análises de sementes de espécies florestais nativas do Rio Grande do Sul. Ciência Florestal, v.21, n.2, p.193-202, 2011. http://cascavel.ufsm.br/revistas/ojs-2.2.2/index.php/ cienciaflorestal/article/view/3221/1866

CAMARGO, J.L.C.; FERRAZ, I.D.K.; MESQUITA, M.R.; SANTOS, B.A.S.; BRUM, H.D. Guia de Propágulos e Plântulas da Amazônia. Manaus: INPA, 2008. 168p.

CHAMBEL, M.R.; CLIMENT, J.; ALÍA, R.; VALLADARES, F. Phenotypic plasticity: a useful framework for understanding adaptation in forest species. Investigación Agraria - Sistemas y Recursos Forestales, v.14, n.3, p.334344, 2005. http://www.inia.es/gcontrec/pub/CHAMBEL-CLIMENT-ALIAVALLADARES_(SRF14-3)_1162282729312.pdf

FERRAZ, I.D.K.; CALVI, G.P. Teste de germinação. In: LIMA JÚNIOR, M.J.V. (Ed.). Manual de procedimentos para análise de sementes florestais. Londrina: ABRATES, 2011. p. 5.1-5.33.

GARWOOD, N.C. Seed germination in a seasonal tropical forest in Panama: a community study. Ecologycal Monographs, v.53, n.2, p.159-181, 1983. http://www.jstor.org/stable/1942493

GARWOOD, N.C. Functional morphology of tropical tree seedlings. In: SWAINE, M.D. (Ed.). The Ecology of Tropical Forest Tree Seedlings. Paris: Parthenon, 1996. p.59-129. 
HOFFMANN, W.A. Post-establishment seedling success in the Brazilian cerrado: a comparison of savanna and forest species. Biotropica, v.32, n.1, p.62-69, 2000. http://onlinelibrary.wiley.com/doi/10.1111/j.1744-7429.2000.tb00448.x/pdf

IBARRA-MANRÍQUEZ, G.; RAMOS, M.M.; OYAMA, K. Seedling functional types in a lowland rain forest in Mexico. American Journal of Botany, v.88, n.10, p.1801-1812, 2001. http://www.jstor.org/stable/ pdfplus/3558356.pdf?acceptTC $=$ true \&acceptTC $=$ true \&jpdConfirm $=$ true

ISTA. INTERNATIONAL SEED TESTING ASSOCIATION. ISTA Handbook on seedling evaluation. Bassersdorf: International Seed Testing Association, 2006.

ISTA. INTERNATIONAL SEED TESTING ASSOCIATION. ISTA Method validation for seed testing. Bassersdorf: International Seed Testing Association, 2007. http://www.seedtest.org/upload/cms/user/ ISTAMethodValidationforSeedTesting-V1.01.pdf

MAIA, L.A.; MAIA, S.; PAROLIN, P. Seedling morphology of non-pioneer trees in central Amazonian varzea floodplain forests. Ecotropica, v.11, n.12, p.1-8, 2005. http://www.gtoe.de/public_html/publications/pdf/11\%201-2/ Maia,\%20Maia\%20\&\%20Parolin,\%202005.pdf

MILANEZ, C.R.D.; OLIVEIRA, D.M.T.; MORAES-DALLAQUA, M.A. Semi-hypogeal germination in Pachyrhizus ahipa (Wedd.) Parodi (FabaceaePhaseoleae): seedling and sapling morphology. Brazilian Archives of Biology and Technology, v.51, n.2, p.353-359, 2008. http://www.scielo.br/pdf/babt/ v51n2/a15v51n2.pdf

MIQUEL, S. Morphologie fonctionnelle de plantules d'espèces forestières du Gabon. Bulletin du Museúm National d'Histoire Naturelle, v.9, n.1, p.101-121, 1987.
RAMOS, K.M.O.; FELFILI, J.M.; FAGG, C.W.; SOUSA-SILVA, J.C.; FRANCO, A.C. Desenvolvimento inicial e repartição de biomassa de Amburana cearensis (Allemão) A.C. Smith, em diferentes condições de sombreamento. Acta Botanica Brasilica, v.18, n.2, p.351-358, 2004. http:// www.scielo.br/pdf/abb/v18n2/v18n02a14.pdf

RANAL, M.A.; SANTANA, D.G. How and why to measure the germination process? Revista Brasileira de Botânica, v.29, n.1, p.1-11, 2006. http://www. scielo.br/pdf/rbb/v29n1/a02v29n1

RESSEL, K.; GUILHERME, F.A.G.; SCHIAVINI, I.; OLIVEIRA, P.E. Ecologia morfofuncional de plântulas de espécies arbóreas da Estação Ecológica do Panga, Uberlândia, Minas Gerais. Revista Brasileira de Botânica, v.27, n.2, p.311-323, 2004. http://www.scielo.br/pdf/rbb/v27n2/v27n2a10.pdf

SARMENTO, M.B.; VILLELA, F.A. Sementes de espécies florestais nativas do sul do Brasil. Informativo ABRATES, v.20, n.1-2, p.39-44, 2010. http:// www.abrates.org.br/portal/images/stories/informativos/v20n12/artigo05.pdf

WRIGHT, I.J.; CLIFFORD, H.T.; KIDSON, R.; REED, M.L.; RICE, B.L.; WESTOBY, M.A. Survey of seed and seedling characters in 1744 Australian dicotyledon species: cross-species trait correlations and correlated trait-shifts within evolutionary lineages. Biological Journal of the Linnean Society, v.69, n.4, p.521-547, 2000. http://onlinelibrary.wiley.com/ doi/10.1111/j.1095-8312.2000.tb01222.x/pdf

ZANNE, A.E.; CHAPMAN, C.A.; KITAJIMA, K. Evolutionary and ecological correlates of early seedling morphology in East African trees and shrubs. American Journal of Botany, v.92, n.6, p.972-978, 2005. http://www. amjbot.org/content/92/6/972.full.pdf + html 